\title{
Sphincterodiplostomum musculosum (Digenea, Diplostomidae) in Geophagus brasiliensis (Perciformes, Cichlidae) collected in a lake at Dois Córregos, São Paulo, Brazil
}

\author{
Sphincterodiplostomum musculosum (Digenea, Diplostomidae) em Geophagus brasiliensis (Perciformes, \\ Cichlidae) coletados em um lago no Município de Dois Córregos, São Paulo, Brasil
}

\author{
Rodrigo Severiano Rocha ${ }^{I}$ Larissa Sbeghen Pelegrini ${ }^{I I}$ Aline de Almeida Camargo ${ }^{\text {II }}$ \\ Vanessa Doro Abdallah ${ }^{I}$ Rodney Kozlowiski de Azevedo ${ }^{{ }^{*}}$
}

ABSTRACT

Geophagus brasiliensis is a freshwater cichlid distributed throughout the whole South America. It is a territorial fish, generally omnivorous, which preferentially inhabits the bottom of water bodies. Previous studies have reported species of digenetic trematodes parasitizing $\boldsymbol{G}$. brasiliensis. This study identifies the Sphincterodiplostomum musculosum Dubois, 1936 a Diplostomidae digenetic, commonly found in many teleostean species. More than $50 \%$ of the hosts analyzed had their eyes infected with metacercariae of $\boldsymbol{S}$. musculosum. A positive correlation was observed between the hosts standard length and the abundance of S. musculosum, a fact that corroborates with other studies on this parasite. This paper reports the first occurrence of $\boldsymbol{S}$. musculosum in $\boldsymbol{G}$. brasiliensis, which is also the first record in Dois Córregos City, São Paulo State, Brazil.

Key words: metacercariae, fish parasites, acará, cichlids, South America.

RESUMO

Geophagus brasiliensis é um ciclídeo de água doce distribuido por toda a América do Sul. É um peixe territorialista, geralmente onívoro, que habita preferencialmente o fundo dos corpos d'água. Há o registro em trabalhos anteriores de espécies de digenéticos parasitando $\boldsymbol{G}$. brasiliensis. O presente estudo traz a identificação de Sphincterodiplostomum musculosum Dubois, 1936, um diplostomídeo comumente encontrado em diversas espécies teleósteas. Mais de 50\% dos hospedeiros analisados estavam com seus olhos parasitados com metacercárias de $\boldsymbol{S}$. musculosum. Houve correlação positiva entre o comprimento padrão dos hospedeiros e a abundância de $\boldsymbol{S}$. musculosum, fato que corrobora com outros trabalhos deste parasito. Este trabalho registra pela primeira vez a ocorrência de $\boldsymbol{S}$. musculosum em $\boldsymbol{G}$. brasiliensis, sendo também a primeira citação deste parasito na região de Dois Córregos, Estado de São Paulo, Brasil.
Palavras-chave: metacercárias, parasitos de peixe, acará, ciclídeos, América do Sul.

\section{INTRODUCTION}

Geophagus brasiliensis (Quoy and Gaimard, 1824), commonly known as acará, is one of the most common fish species in Brazil, with a large adaptation capacity to lentic environments and with high abundance in lakes and reservoirs. They are Perciformes, belonging to the Cichlidae, and distributed in the South America (mainly in Brazil and Uruguay), from the Amazon to the Paraná Basin (KULLANDER, 2003; MORAES et al., 2004). They are territorial fishes with solitary habits that preferentially inhabit the bottom of water bodies, and whose feeding is diverse in the adult stage, including gastropods, arthropods, plant debris, sediments, algae and other items sorted with their protractile mouth. The juvenile fishes basically feed with insect larvae (LAZZARO, 1991; MORAES et al., 2004).

Studies carried out on the parasite fauna of $\boldsymbol{G}$. brasiliensis were mostly done with records of specimens from lotic environments, like the works performed by PINTO \& NORONHA (1976); BOEGER \& POPAZOGLO (1995); FERNANDES \& KOHN (2001); KOHN et al. (2003); AZEVEDO et al. (2006); BELLAY et al. (2008; 2012), CARVALHO

'Laboratório de Ictioparasitologia, Central de Laboratórios de Pesquisa em Ciência e Tecnologia Ambiental, Universidade do Sagrado Coração (USC), São Paulo, SP, Brasil.

IIPrograma de Pós-graduação em Ciências Biológicas, Instituto de Biociências, Universidade Estadual Paulista (UNESP), Campus de Botucatu, Av. Prof. Montenegro, s/n, Distrito de Rubião Junior, 18618-970, Botucatu, SP, Brasil. E-mail: azevedork@gmail.com. *Corresponding author. 
et al. (2008a; 2008b; 2012) and BRANDÃO et al. (2014); the studies on parasites of G. brasiliensis from lentic environments are scarce.

Among the parasites that infect $\boldsymbol{G}$. brasiliensis, the digenetic trematodes Diplostomidae Poirier, 1886 are relatively common in studies involving this host. They are parasites of large distribution in South America, found in many other freshwater fish species. Metacercariae of this family parasitizes internal and external eyes structures, the digestive tract, among other fish organs (CHAPPELL, 1995). They have foliaceus body dorsoventrally flattened and can present two distinct regions: the anterior part generally concave turned to the ventral side and the posterior portion connected to it forming a conical extension (SZIDAT, 1969).

Thus, this study aimed the taxonomic determination of metacercariae parasities of $\boldsymbol{G}$. brasiliensis collected in a lacustrine environment of Dois Córregos City, São Paulo State, with a morphometric analysis of parasites and considerations on their host distribution.

\section{MATERIAL AND METHODS}

This study carried out the analysis of 50 specimens of $\boldsymbol{G}$. brasiliensis from a lake located in the rural area of the São Francisco farm, $5.5 \mathrm{~km}$ from the urban area of Dois Córregos $\left(-48^{\circ} 25^{\prime} 50,21\right.$ 'S $-22^{\circ} 22^{\prime} 09,42^{\prime}$ W), in São Paulo State, Brazil, with an altitude of $655.52 \mathrm{~m}$.

The collections were carried out from March to June, 2013. The gill nets with different meshes used to collect the fishes following the guidelines of the scientific fishing license, whose number is SISBIO n. 40998-2, which deals with the permit to exploit fisheries resources and research on wild animals, according to the ICMBio legislation.

Immediately after the removal of the gill nets, the fishes were packed in individual plastic bags. The analyses were done at the Ictioparasitology Laboratory - Universidade do Sagrado Coração USC in Bauru, SP. Eyes were extracted and the parasites were removed from the vitreous humor, counted, fixed and, then, identification plates were prepared with Mayer's carmalum staining according to EIRAS et al. (2006). Morphological analysis was carried out using the microscope Trinocular Nikon E200, and the morphometry was obtained through the Motic computerized image analysis system (Moticam 5.0MP). The measures of the 15 specimens measured are provided in micrometers; the mean is followed by the standard deviation and variation range.
The quantitative descriptors were obtained according to BUSH et al. (1997). The Spearman's Rank Correlation Coefficient (rs) was applied in order to detect possible existing correlations between the parasite abundance and the host size, and the parasite abundance and the host weight (ZAR, 1995).

Representative specimens were deposited in the Coleção Helmintológica do Instituto de Biociências de Botucatu (CHIBB) at the Universidade Estadual Paulista - UNESP, in Botucatu City, São Paulo State, Brazil, with the number CHIBB 131L.

\section{RESULTS AND DISCUSSION}

Fishes presented a mean weight of $10.22 \pm 3.85 \mathrm{~g}$ and a mean standard length of $7.05 \pm 0.85 \mathrm{~cm}$. An amount of 155 metacercariae was collected in the eyes of more than $50 \%$ of the hosts analyzed. All parasites were identified as Sphincterodiplostomum musculosum Dubois, 1936 metacercariae (Figure 1).

The specimens of Sphincterodiplostomum are characterized by the presence of one dorsal tubular invagination at level of posterior testis, equipped with a sphincter. Sphincterodiplostomum musculosum is characterized for presenting two distinct portions. In the anterior portion, there are the vitellaria, the oral sucker with two pseudosuckers around it, the ventral suckers and the tribocitic organ. The posterior portion presents an ovary, a pair of testicles and a subterminal sphincter (SZIDAT, 1969; CESCHINI et al., 2010). This species was described for the first time in Agamia agami (Gmelin, 1789) (Ardeidae) in Brazil, with adult samples in this bird intestine (DUBOIS, 1936). Metacercariae of $\boldsymbol{S}$. musculosum were reported in fishes such as Cyphocharax gilbert (Quoy and Gaimard, 1824) (ABDALLAH et al., 2005), Prochilodus lineatus Valenciennes, 1836 (LIZAMA et al., 2006), Hoplias malabaricus Bloch, 1794, Hemisorubim platyrhynchos Valenciennes, 1840 (TAKEMOTO et al., 2009), Steindachnerina brevipinna Eigenmann and Eigenmann, 1889 (CESCHINI et al., 2010) and Steindachnerina insculpta Fernández-Yépez, 1948 (ZAGO et al., 2013; BRANDÃO et al., 2014).

Regarding the parasite indexes, the metacercariae found presented a mean abundance of $3.10 \pm 0.11$ and a mean intensity of $5.97 \pm 0.21$. ZAGO et al. (2013) and BRANDÃO et al. (2014) found superior quantitative descriptors of $\boldsymbol{S}$. musculosum in the analysis of $\boldsymbol{S}$. insculpta, with prevalence above $93 \%$ and mean intensity and abundance above 35.3 . 


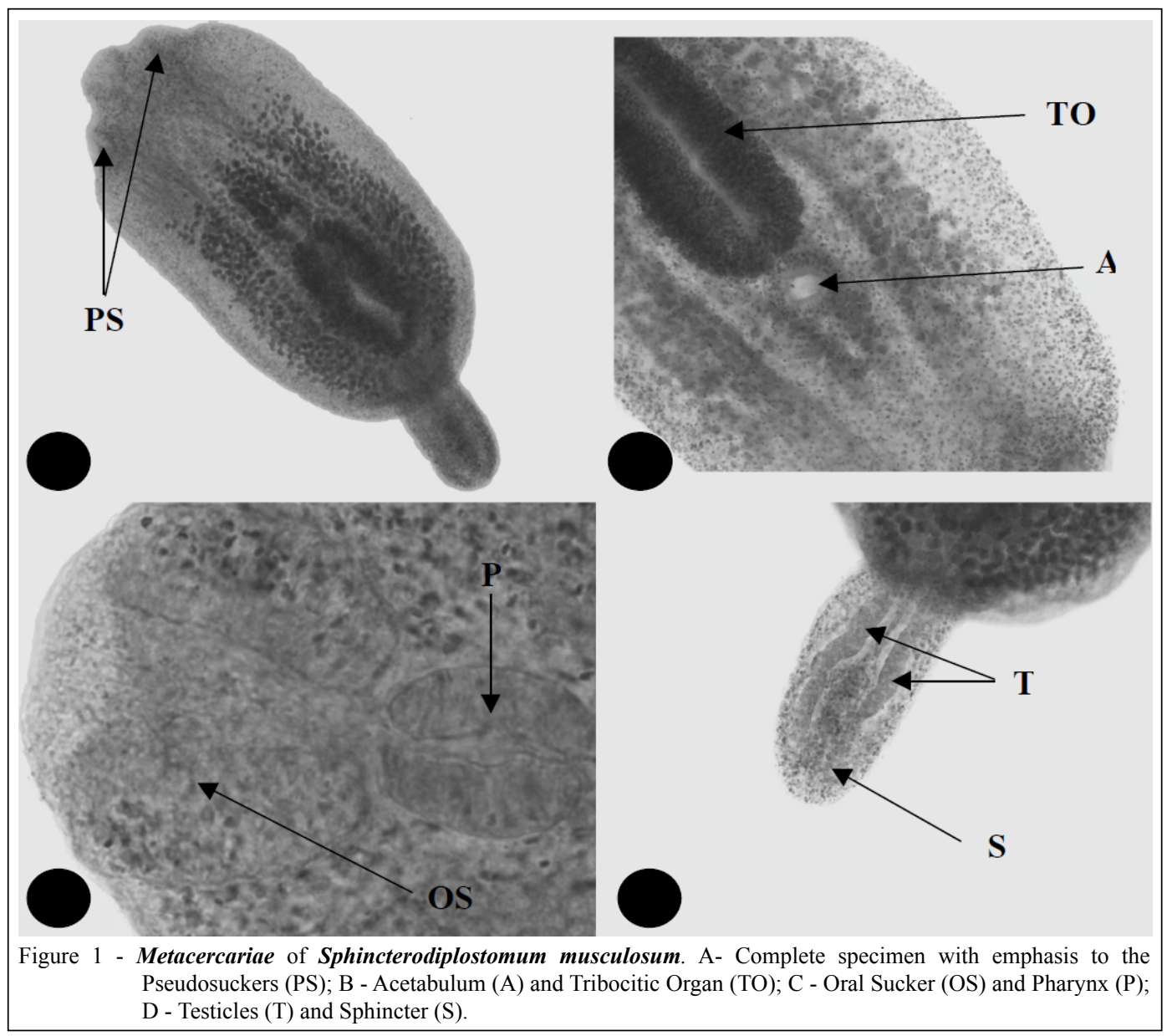

There was a positive correlation between the abundance of $\boldsymbol{S}$. musculosum and the hosts standard length $(r=0.58 ; \mathrm{P}=0.02)$. Such pattern was also found by CESCHINI et al. (2010), in studies with $\boldsymbol{S}$. brevipinna in the low Paranapanema river; and also in researches with $\boldsymbol{S}$. insculpta by ZAGO et al. (2013) in the middle Paranapanema, and by BRANDÃO et al. (2014) in the high Paranapanema. Such similar results give support to the idea of a parasites cumulative effect through the host's growth as there is the increase of the area available for infection. Besides, as the body surface increases along the host ontogenetic development, the possibilities of occurring active penetration of cercariae increases (LUQUE et al., 1996).

The measures of $\boldsymbol{S}$. musculosum recorded in this study were smaller than the ones obtained by CESCHINI et al. (2010) and ZAGO et al. (2013) (Table 1). According to CHAPPEL (1995) and SALDANHA et al. (2009), the metacercariae body dimensions can vary according to several factors such as size, age and species of the host, level of aggregation and the intensity-dependent growth of the helminths within the host, helminth condition in the moment of fixing and the fixing technique used.

The pathogenic significance of digeneans in fishes is much more pronounced in infections by metacercariae than by adults because these encyst in any tissue or organ, except in cartilage or bones, weak the host (EIRAS, 1994; THATCHER, 2006). KENNEDY (1981) explains the parasitism by Diplostomum spathaceum (Rudolphi, 1819), one diplostomidae eyes parasite of several fish species, can cause the formation of cataracts on the lenses ("white eye"), and there is often no other pathology associated, so these fishes can acumulate the metacercariae in the eyes throughout many seasonal periods. In extreme cases, the infection effect by diplostomidae causes more severe effects such as exophthalmos, retinal detachment, cataracts, lens opacity and blindness, causing weight loss and the consequent host death due to inability to visualize and capture the prey, or because they cannot evade potential predators (PENNYCUICK, 1971). This 
Table 1 - Comparison between the morphometric data of metacercariae of Sphincterodiplostomum musculosum collected in Geophagus

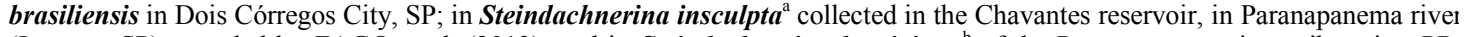
(Ipaussu, SP) recorded by ZAGO et al. (2013); and in Steindachnerina brevipinna ${ }^{\mathrm{b}}$ of the Paranapanema river tributaries, PR. recorded by CESCHINI et al. (2010) (measures in $\mu \mathrm{m}$ ).

\begin{tabular}{|c|c|c|c|}
\hline $\begin{array}{l}\text { Measures of the metacercariae of } \\
\text { S. musculosum }\end{array}$ & $\begin{array}{c}\text { G. brasiliensis } \\
\text { Average } \pm \text { SD (Amplitude) }\end{array}$ & $\begin{array}{c}\text { S. } \text { insculpta }^{a} \\
\text { Average } \pm \text { SD (Amplitude) }\end{array}$ & $\begin{array}{c}\text { S. } \text { brevipinna }^{\boldsymbol{b}} \\
\text { Average (Amplitude) }\end{array}$ \\
\hline Length of the anterior segment & $797.18 \pm 87.64(449.58-952.45)$ & $1642.6 \pm 330.9(1133.9-2346.9)$ & $1530(1150-1900)$ \\
\hline Width of the anterior segment & $454.88 \pm 85.88(343.21-497.75)$ & $1272.4 \pm 230.9(914.4-1844.3)$ & $1508(1075-1675)$ \\
\hline Length of the posterior segment & $268.34 \pm 40.12(224.11-343.75)$ & $1087.4 \pm 259.9(810.9-1811.1)$ & $1033(600-1375)$ \\
\hline Width of the posterior segment & $133.28 \pm 18.38(100.11-158.07)$ & $572.8 \pm 79.4(452.8-745.4)$ & $665(500-800)$ \\
\hline Length of the tribocitic organ & $255.24 \pm 33.36(185.31-288.89)$ & $391.5 \pm 85.1(246-644.6)$ & $384(290-440)$ \\
\hline Width of the tribocitic organ & $138.69 \pm 11.93(114.62-156.60)$ & $494.9 \pm 107.2(321.2-732.4)$ & $490(350-650)$ \\
\hline Length of the oral sucker & $90.97 \pm 9.79(69.40-104.93)$ & $142.4 \pm 34.5(96.3-292.6)$ & $145(100-200)$ \\
\hline Width of the oral sucker & $97.71 \pm 7.47(77.08-109.39)$ & $180.5 \pm 31.5(134.8-313.6)$ & $213(130-200)$ \\
\hline Length of the acetabulum & $69.78 \pm 7.97(57.49-82.44)$ & $142.4 \pm 34.5(96.3-292.6)$ & $162(130-210)$ \\
\hline Width of the acetabulum & $80.53 \pm 7.85(66.34-96.40)$ & $180.5 \pm 31.5(134.8-313.6)$ & $213(180-250)$ \\
\hline Pharyngeal length & $56.6 \pm 4.16(50.96-65.38)$ & $114.8 \pm 27.5(89.6-218.5)$ & $104(84-117)$ \\
\hline Pharyngeal width & $48.68 \pm 6.69(38.24-57.24)$ & $73.1 \pm 16.1(47.9-113.4)$ & $54(45-84)$ \\
\hline Length of the larger testicle & $44.28 \pm 22.43(22.26-44.39)$ & $310.1 \pm 58.9(210-446.6)$ & $290(210-400)$ \\
\hline Width of the larger testicle & $31.19 \pm 8.59(21.51-44.31)$ & $385.1 \pm 79.6(275.2-557.9)$ & $410(200-510)$ \\
\hline Length of the smaller testicle & $23.51 \pm 5.05(18.48-31.31)$ & $285.4 \pm 62.2(199.8-452.7)$ & $217(130-390)$ \\
\hline Width of the smaller testicle & $25.18 \pm 1.88(23.26-31.76)$ & $293.2 \pm 49.8(209.4-414.3)$ & $307(250-350)$ \\
\hline Length of the ovary & $30.33 \pm 9.22(17.77-39.98)$ & - & - \\
\hline Width of the ovary & $26.35 \pm 4.62(21.96-32.56)$ & - & - \\
\hline
\end{tabular}

$\mathrm{SD}=$ standard deviation

research highlights that the host behavior can suffer direct or indirect influence of the parasite action, as physical and chemical changes can occur due to parasitism, according to CORRÊA et al. (2014).

Geophagus brasiliensis is a small species with territorial and benthic behavior. Such characteristics make this species a potential intermediate host as its size and location in the lowest levels in the food chain are assumptions that this might serve as food to definitive hosts. Benthic habit also facilitates the increase of wealth and abundance of parasitic larvae since the fishes tend to stay close to the bottom, in touch with clams or other invertebrates that will act as the first intermediate hosts for Digenea (GEORGE-NASCIMENTO, 1987; MARCOGLIESE, 2002).

Other studies bring the digenetic record in eyes of $\boldsymbol{G}$. brasiliensis. Metacercariae of Diplostomum (Autrodiplostomum) compactum Lutz, 1928 (Diplostomidae) were found parasitizing the eyes of $\boldsymbol{G}$. brasiliensis in the Tietê river (São Paulo) (NOVAES et al., 2006) and in reservoirs of the Paraná State (BELLAY et al., 2012). The specimens collected by AZEVEDO et al. (2006) in Guandu river (Rio de Janeiro), also had their eyes parasitized by $\boldsymbol{D}$. (A.) compactum, and two other metacercariae were identified: Posthodiplostomum macrocotyle and Strigeidae metacercariae.

\section{CONCLUSION}

This study present the first record of $\boldsymbol{S}$. musculosum parasitizing $\boldsymbol{G}$. brasiliensis, showing a new occurrence location in Dois Córregos City in São Paulo State, enlarging, therefore, its geographical distribution.

The positive correlation between the abundance of $\boldsymbol{S}$. musculosum and the standard length of the hosts is a model that repeated is itself in this research when compared with other studies involving this parasite. However, morphometric data of $\boldsymbol{S}$. musculosum in $\boldsymbol{G}$. brasiliensis presented smaller dimensions regarding the other studies on this parasite, showing that such metacercariae could have infected this host for less time.

\section{ACKNOWLEDGEMENTS}

The authors would like to thank Leila Felipini for editing the English. This study was supported by the Fundação de Amparo à Pesquisa do Estado de São Paulo (FAPESP), processes n. 2014/06332-8 and 2012/23655-0; Coordenação de Aperfeiçoamento de Pessoal de Nível Superior (CAPES); and Conselho Nacional de Desenvolvimento Científico e Tecnológico (CNPQ). 


\section{REFERENCES}

ABDALLAH, V.D. et al. Ecologia da comunidade de metazoários parasitos do sairú Cyphocharax gilbert (Quoy e Gaimard, 1824) (Characiformes: Curimatidae) do rio Guandu, Estado do Rio de Janeiro, Brasil. Revista Brasileira de Parasitologia Veterinária v.14, n.4, p.154-159, out/dez. 2005. Available from: <http:// www.cbpv.org.br/rbpv/documentos/1442005/c144154_159.pdf>. Accessed: Feb. 08, 2014

AZEVEDO, R.K. et al. Ecologia da comunidade de metazoários parasitos do acará Geophagus brasiliensis (Quoy e Gaimard, 1824) (Perciformes: Cichlidae) do rio Guandu, Estado do Rio de Janeiro, Brasil. Acta Scentiarum Biological Sciences, v.28, n.4, p.403-411, dez. 2006. Available from: <http://periodicos.uem.br ojs/index.php/ActaSciBiolSci/ article/ view/406>. Accessed: Feb. 12, 2014 doi: 10.4025 /actascibiolsci.v28i4.406.

BELLAY, S. et al. A new species of Sciadicleithrum (Monogenea: Ancyrocephalinae), gill parasite of Geophagus brasiliensis (Quoy \& Gaimard) (Teleostei: Cichlidae) from reservoirs in the State of Paraná, Brazil. Zootaxa, v.1700, p.63-68, fev. 2008.

BELLAY, S. et al. Fauna parasitária de Geophagus brasiliensis (Perciformes: Cichlidae) em reservatórios do estado do Paraná, Brasil. Revista Brasileira de Biociências, v.10, n.1, p.74-78, jan./mar. 2012. Available from: <http://www.ufrgs.br/seerbio/ojs/ index.php/rbb/article/ view/1993>. Accessed: Jun. 16, 2014.

BOEGER, W.A.; POPAZOGLO, F. Neotropical Monogenoidea 23. Two new species of Gyrodactylus (Gyrodactylidae) from a Cichlid and an Erythrinid fish of Southeastern Brazil. Memórias do Instituto Oswaldo Cruz, v.90, n.6, p.689-694, nov./dez. 1995. Available from: <http://www.bioline.org.br/request?oc95140>. Accessed: Jun. 08, 2014.

BRANDÃO, H. et al. Parasitism by Sphincterodiplostomum musculosum (Digenea, Diplostomidae) metacercariae in the eyes of Steindachnerina insculpta (Characiformes, Curimatidae). Revista Brasileira de Parasitologia Veterinária, v.23, n.2, p.144-149, abr/jun 2014. Available from: <http://www.scielo.br/ scielo.php?pid=S1984-29612014000200144\&script $=$ sci arttext $>$. Accessed: Aug. 22, 2014. doi: 10.1590/S1984-29612014038.

BUSH, A.O. et al. Parasitology meets ecology on its own terms Margolis et al. revisited. Journal of Parasitology, v.83, n.4, p.575-583, ago. 1997. Available from: <http://www.fcfar.unesp. br/arquivos/494986.pdf>. Accessed: Jul. 05, 2014.

CARVALHO, A.R. et al. A new species of Sciadicleithrum (Monogenea, Dactylogyridae) parasitic on Geophagus brasiliensis (Perciformes, Cichlidae) from Guandu River, Southeastern Brazil. Acta Parasitologica, v.53, n.3, p.237-239, 2008a. Available from: $<$ http://link.springer.com/article/10.2478\%2Fs11686-008-00356\#page-1>. Accessed: Jul. 03, 2014. doi: 10.2478/s11686-008-0035-6.

CARVALHO, A.R. et al. Metacercárias tipo Neascus em Geophagus brasiliensis (Perciformes: Cichlidae) do rio do Peixe, Juiz de Fora, Brasil. Acta Scientiarum Biological Sciences, v.30, n.3, p.315-320, jun. 2008b. Available from: <http://www.ufrrj.br/ laboratorio/parasitologia/arquivos/publicacao/38_LIVRO.pdf>. Accessed: Apr. 07, 2014. doi: 10.4025/actascibiolsci.v30i3.493.

CARVALHO, A.R. et al. Metacercárias de Diplostomidae (Digenea: Diplostomoidea) em Geophagus brasiliensis (Perciformes: Cichlidae) do rio Guandu, Estado do Rio de Janeiro,
Brasil. Acta Scentiarum Biological Sciences, v.34, n.2, p.233239, abr./jun. 2012. Available from: $<$ http://periodicos.uem.br/ojs/ index.php/ActaSciBiolSci/article/view/5957>. Accessed: Mar. 23, 2014. doi: 10.4025/actascibiolsci.v34i2.5957.

CESCHINI, T.L. et al. Endoparasites of Steindachinerina brevipinna (Eigenmann and Eigenmann, 1889), collected in the tributaries Corvo and Guairacá of Paranapanema river, State of Paraná, Brazil. Acta Scentiarum Biological Sciences, v.32, n.2, p.125-130, fev. 2010. Available from: <http://periodicos.uem. br/ojs/index.php/ActaSciBiolSci/article/viewFile/4102/4102>. Accessed: Mar. 17, 2014 doi: 10.4025/actascibiolsci.v32i2.4102.

CHAPELL, L.H. The biology of diplostomatid eyeflukes of fishes. Journal of Helminthology, v.69, n.1, p. 97101, jun. 1995. Available from: <https://archive.org/details/ revuesuissedezoo4319schw>. Accessed: Mar. 12, 2014 . doi: 10.1017/S0022149X00013961.

CORRÊA, L.L. et al. Behavioral changes caused by Austrodiplostomum spp. in Hoplias malabaricus from the São Francisco River, Brazil. Parasitology Research, v.113, n.2, p.499-503, nov. 2014. Available from: <http://link.springer.com/ar ticle/10.1007\%2Fs00436-013-3679-6>. Accessed: Apr. 14, 2014. doi: 10.1007/s00436-013-3679-6.

DUBOIS, G. Nouveaux principes de classification dês Trématodes du groupe des Strigeida (Notes préliminaires). Revue Suisse de Zoologie, v.43, n.3, p.507-515, May. 1936. Available from: $<$ https://archive.org/details/revuesuissedezoo4319schw $>$. Accessed: May 04, 2014

EIRAS, J.C. Elementos de ictioparasitologia. Portugal: Fundação Eng. António de Almeida, Portugal, 1994. 339p.

EIRAS, J.C. et al. Métodos de estudo e técnicas laboratoriais em parasitologia de peixes. Maringá: Eduem, 2006. 199p.

FERNANDES, B.M.M.; KOHN, A. On some trematodes parasites of fishes from Paraná River. Brazilian Journal of Biology, v.61, n.3, p.461-466, ago. 2001. Available from: <http://www.scielo. br/scielo.php?pid $=$ S 1519-69842001000300016\&script $=$ sci arttext $>$. Accessed: Jun. 21, 2014 . doi: 10.1590/S151969842001000300016

GEORGE-NASCIMENTO, M. Ecological helminthology of wildlife animal hosts from South America: a literature review and a search for patterns in marine food webs. Revista Chilena de Historia Natural, v.60, n.2, p.181-202, nov. 1987. Available from: <http:// rchn.biologiachile.cl/pdfs/1987/2/George-Nascimento 1987.pdf>. Accessed: May 02, 2014.

KENNEDY, C.R. Long term studies on the population biology of two species of eyefluke, Diplostomum gasterostei and Tylodelphys clavata (Digenea: Diplostomatidae), concurrently infecting the eyes of perch, Perca fluviatilis. Journal of Fish Biology, v.19, n.2, p.221-236, ago. 1981. Available from: <http://onlinelibrary.wiley. com/doi/10.1111/j.1095-8649.1981. tb05826.x/pdf>. Accessed: Mar. 12, 2014. doi: 10.1111/j.1095-8649.1981.tb05826.x.

$\mathrm{KOHN}$, A. et al. Helmintos em peixes do Reservatório de Itaipu e áreas de influência. Revista Brasileira de Medicina Veterinária, v.25, n.4, p.148-153, 2003.

KULLANDER, S.O. Family Cichlidae. In R.E. REIS, S.O. (Ed.). Checklist of the Freshwater Fishes of South and Central America. Porto Alegre: Edipucrs, 2003. p.605-654. 
LAZZARO, X. Feeding convergence in South American and African zooplanktivorous cichlids Geophagus brasiliensis and Tilapia rendalli. Environmental Biology Fishes, v.31, n.3, p.283293, jul. 1991.

LIZAMA, M.A.P. et al. Parasitism influence on the hepato, splenosomatic and weight/length relation and relative condition factor of Prochilodus lineatus (Valenciennes, 1836) (Prochilodontidae) of the Upper Paraná River Floodplain, Brazil. Revista Brasileira de Parasitologia Veterinária, v.15, n.3, p.116122, jul. 2006. Available from: <http://www.cbpv.org.br/rbpv/ documentos/1532006/c153116_122.pdf>. Accessed: May 02, 2014.

LUQUE, J.L. et al. Comparative analysis of the communities of metazoan parasites of Orthopristis ruber and Haemulon steindachneri (Osteichthyes: Haemulidae) from the southeastern Brazilian littoral: 1. Structure and influence of the size and sex of hosts. Revista Brasileira de Biologia, v.56, n.2, p.279-292, may 1996.

MARCOGLIESE, D.J. Food webs and the transmission of parasites to marine fish. Parasitology, v.124, n.7, p.83-99, out. 2002. Available from: <http://journals.cambridge. org/action/disp layAbstract? fromPage $=$ online $\&$ aid $=120231>$. Accessed: Apr. 09, 2014. doi: 10.1017/S003118200200149X.

MORAES, M.F.P. et al. Feeding habits and morphometry of digestive tracts of Geophagus brasiliensis (Osteichthyes, Cichlidae), in a lagoon of High Tibagi River, Paraná State, Brazil. Publicatio UEPG: Ciências Biológicas e da Saúde, v.10, n.1, p.37-45, mar. 2004.

NOVAES, J.L.C. et al. Metacercariae of Diplostomum compactum Lutz, 1928 (Trematoda, Diplostomidae) in the eyes of acará Geophagus brasiliensis (Quoy \& Gaimard, 1824) (Teleostei, Cichlidae) from Barra Bonita Reservoir - São Paulo, Brazil. Arquivos Brasileiros de Medicina Veterinária e Zootecnia, v.58, n.6, p.1229-1231, dez. 2006. Available from: $<$ http://www.scielo.br/ scielo.php?script $=$ sci_arttext\&pid $=$ S0102-09352006000600037>. Accessed: Apr. 14, 2014. doi: 10.1590/S0102-09352006000600037.

PENNYCUICK, L. Quantitative effects of three species of parasites on a population of three-spined sticklebacks, Gasterosteus aculeatus. Journal of Zoology, v.165, n.2, p.143-162, out. 1971. Available from: <http://www.scielo.br/pdf/bjb/v69n2s0/ v69n2s0a23.pdf $>$. Accessed: Mar. 27, 2014. doi: 10.1111/j.14697998.1971.tb02179.x.

PINTO, R.M.; NORONHA, D. Procamallanus brasileiros (Nematoda, Camallanoidea): considerações finais, com chave para determinação das espécies. Memórias do Instituto Oswaldo Cruz, v.74, n.3-4, p.323-339. 1976. Available from: <http:// www.scielo.br/pdf/mioc/v74n3-4/tomo74(f3-4)_130-146.pdf $>$. Accessed: Jul. 04, 2014. doi: 10.1590/S0074-02761976000300011.

SALDANHA, I. Causes of intraspecific variation in body size among trematode metacercariae. Journal of Helmintthology, v.83, n.3, p.289-293, set. 2009. Available from: $<$ http://journals. cambridge.org/action/displayAbstract? fromPage $=$ online $\&$ aid $=60$ 05800\&fileId=S0022149X09224175\#>. Accessed: Apr. 12, 2014. doi: 10.1017/S0022149X09224175.

SZIDAT, L. Structure, development, and behaviour of new strigeatoid Metacercariae from subtropical fishes of South America. Journal of the Fisheries Research Board of Canada, v.26, n.4, p.753-786, set. 1969. Available from: <http://www. nrcresearchpress.com/doi/pdf/ 10.1139/f69-074>. Accessed: Mar. 04, 2014. doi: 10.1139/f69-074.

TAKEMOTO, R.M. et al. Diversity of parasites of fish from the Upper Paraná River floodplain, Brazil. Brazilian Journal of Biology, v.69, n.S2, p.691-705, jun. 2009. Available from: $<$ http:// www.scielo.br/pdf/bjb/v69n2s0/v69n2s0a23.pdf $>$. Accessed: Mar. 27, 2014. doi: 10.1590/S1519-69842009000300023.

THATCHER, V.E. Amazon fish parasites. 2 ed. Sofia: Pensoft, 2006. 508p.

ZAGO, A.C. et al. Sphincterodiplostomum musculosum (Digenea, Diplostomidae) infecting Steindachnerina insculpta (Characiformes, Curimatidae) in the Chavantes Reservoir, Southeastern Brazil. Revista Brasileira de Parasitologia Veterinária, v.22, n.1, p.98-103, jan-mar. 2013. Available from: $<$ http://www.scielo.br/scielo.php?pid=S 1984 $29612013000100098 \& \mathrm{script}=\mathrm{sci}$ arttext\&tlng $=\mathrm{pt}>$. Accessed:Apr. 13, 2014. doi: 10.1590/S1984-29612013000100018.

ZAR, J.H. Biostatistical analysis. New Jersey: Prentice-Hall, 1999. 663p. 